\title{
Nilai Tambah dan Sikap Konsumen Produk Brownies Berbahan Baku Tepung Ubi Kayu Tinggi Protein
}

Zukryandrya, Annisa Fitri b, Beni Hidayatc

aProgram Studi Teknologi Pangan Politeknik Negeri Lampung, email: zukryandry@polinela.ac.id

bProgram Studi Agribisnis Pangan Politeknik Negeri Lampung, email: annisafitrihasibuan@polinela.ac.id cProgram Studi Teknologi Pangan Politeknik Negeri Lampung, email: beni_lpg@polinela.ac.id

\section{Article Info}

\section{Article history:}

Received 29 December 2020

Received in revised from 18 January 2021

Accepted 04 March 2021

DOI:

https://doi.org/10.32938/ag.v6i2.1245

\section{Keywords:}

Brownies

Added Value

Consumer Attitudes

High Protein Cassava Flour

\begin{abstract}
Abstrak
The added value of high protein cassava flour to brownies shows the potential of the product to be developed. Producers of brownies made from high protein cassava flour must be oriented towards consumer interests, namely producing products that are in accordance with consumer demands and desires. This research aimed to analyze the added value of high protein cassava flour as a raw material for making steamed brownies and to analyze consumer attitudes towards steamed brownie products made from high protein cassava flour. This study used cross section data from high-protein cassava flour brownies and 25 consumers. The method of value added analysis used is the Hayami method and fishbein for analysis of consumer properties. The results showed that the added value of brownies made from high protein cassava flour: Rp.29.356 kg with a value added ratio of 49.92 high category. Overall consumer attitudes are positive for high protein cassava flour brownies and the attributes that are considered for purchasing high protein cassava flour brownies include taste and price.
\end{abstract}

\section{Pendahuluan}

Substitusi tepung terigu dengan tepung lokal adalah cara untuk mengurangi impor gandum dalam pembuatan terigu. Komoditas yang dapat mensubtitusi gandum sebagai bahan baku tepung terigu adalah komoditas ubi kayu dan ubi jalar. Produktivitas tanaman ubi kayu di Provinsi Lampung menduduki urutan teratas di Indonesia yaitu 7.387.084 ton (BPS, 2018), dengan demikian Provinsi Lampung sangat prospektif dalam pengembangan bahan pangan tepung ubi kayu.

Susanto (2013) menyatakan pembuatan tepung ubi kayu sangat prospektif, karena tepung ubi kayu belum dikenal masyarakat, walaupun penelitian berkaitan dangan ubi kayu banyak dilakukan. Husniah et al., (2019) industri hasil pertanian yang menghasilkan aneka ragam produk olahan adalah salah satu bentuk agroindustri. Tepung ubi kayu tinggi protein untuk bahan baku olahan pangan adalah contoh agroindustri dan sebagai penunjang diversifikasi pangan lokal di Provinsi Lampung. Menurut Hidayat et al., (2018) tepung ubi kayu dapat digunakan untuk membuat berbagai produk olahan pangan diantaranya makanan ringan, aneka roti, kue kering dan cake. Salah satu cake sebagai penganekaragaman pangan adalah brownies berbahan baku tepung ubi kayu tinggi protein. Brownies sudah dikenal sejak lama sekitar akhir abad ke 19 di Amerika Serikat. Produk ini adalah panganan yang dipanggang atau dikukus dengan aneka bentuk seperti segi empat atau berbentuk bar. Brownies adalah produk yang disukai mayrakat Indonesia dari bergai usia dan status sosial. Bahan utama pembuatan brownies adalah tepung terigu dan coklat batang / dark compound chocolate (Sari et al., 2020).

Proses pengolahan tepung ubi kayu tinggi protein menjadi brownies akan memberi peningkatan nilai tambah komoditas pertanian, dimana peningkatan tersebut diperlukan adanya biaya pengolahan. Menurut Ruauw (2015) bahwa pertambahan nilai komoditas suatu produk seperti proses penanganan, proses pengiriman dan proses pergudangan pada kegiatan produksi disebut nilai tambah (value added). Adanya penambahan nilai pada produk tepung ubi kayu tinggi protein menjadi brownies perlu diketahui, hal ini menunjukkan potensi dari suatu produk untuk dikembangkan. Potensi tersebut dapat terlihat apabila tepung ubi kayu diolah menjadi brownies memberikan keuntungkan untuk pelaku usaha.

Kondisi pasar yang selalu berubah mengakibatkan semakin banyak pelaku usaha dibidang brownies berbahan baku tepung terigu. Hal tersebut mengakibatkan tingginya persaingan antar produsen brownies. Persaingan ini mengharuskan produsen untuk selalu berorientasi kepada kepentingan konsumen, yaitu produk brownies yang diinginkan konsumen. Pendapat Adiyoga dan Nurmalinda (2012) bahwa seseorang menyukai produk, apabila produk tersebut memberikan kepuasan baik dalam hal keinginan maupun kebutuhan bagi konsumen. Kegiatan analisis yang dapat dijadikan masukan bagi pengusaha dalam menentukan strategi pemasaran adalah mengetahui sikap konsumen terhadap brownies tepung ubi kayu tinggi protein. Penelitian ini bertujuan (1) Melakukan analisis nilai tambah (value added) tepung ubi kayu tinggi protein sebagai bahan baku pembuatan brownies (2) Menganalisis sikap konsumen terhadap produk brownies berbahan baku tepung ubi kayu tinggi protein. 


\section{Metode}

Penelitian dilaksanakan di Laboratorium THP dan unit produksi Roti Kampus Politeknik Negeri Lampung pada bulan November 2019 sampai bulan April 2020. Data yang diolah adalah data primer dengan wawancara langsung terhadap pelaku usaha brownies dan konsumen sebagai sumber informasi utama dengan menggunakan daftar pertanyaan. Model data menggunakan cross section yang merupakan data dalam satu kurun waktu. Teknik sampling dalam penelitian ini menggunakan metode accidental sampling sejumlah 25 konsumen. Nilai tambah menurut Hamidah et al., (2015) merupakan penambahan nilai komoditas baik produk yang mengalami proses penanganan, proses pengiriman atau proses penggudangan didalam kegiatan produksi. Analisis nilai tambah diketahui dengan upah yang diterima oleh karyawan. Tabel 1 berikut merupakan cara menghitung nilai tambah berdasarkan metode Hayami.

Penilaian kriteria nilai tambah berdasarkan Mumpuningsih (2008):

1) Apabila nilai tambah lebih dari nol, maka usaha pengolahan memiliki nilai tambah positif.

2) Apabila nilai tambah kurang dari nol, maka usaha pengolahan memiliki nilai tambah negatif.

Tabel 1. Langkah-Langkah Menghitug Nilai Tambah

No

\section{Variabel}

\section{Notasi}

\begin{tabular}{|c|c|c|}
\hline \multicolumn{3}{|c|}{ I. Output, Input, dan Harga } \\
\hline 1 & Pengeluaran / total kegiatan produksi (Kg/ produksi) & (1) \\
\hline 2 & Pemasukan bahan baku (Kg/produksi) & (2) \\
\hline 3 & Karyawan (HOK/produksi) & (3) \\
\hline 4 & Konversi satuan & $(4)=(1) /(2)$ \\
\hline 5 & Koefisien karyawan & $(5)=(3) /(2)$ \\
\hline 6 & Harga jual (Rp/unit) & (6) \\
\hline 7 & Upah rata-rata karyawan per HOK $(\mathrm{Rp})$ & (7) \\
\hline \multicolumn{3}{|c|}{ II. Penerimaan dan Keuntungan } \\
\hline 8 & Harga pemasukan bahan baku (Rp/Kg) & (8) \\
\hline 9 & Sumbangan pemasukan lainnya (Rp/Kg) & (9) \\
\hline 10 & Nilai pengeluaran $(\mathrm{Rp} / \mathrm{Kg} /)$ & $(10)=(4) \times(6)$ \\
\hline 11 & a. Value added $(\mathrm{Rp} / \mathrm{Kg})$ & $(11 a)=(10)-(9)-(8)$ \\
\hline & b. Perbandingan value added (\%) & $(11 b)=[(11 a) /(10)] \times 100 \%$ \\
\hline 12 & a. Pendapatan karyawan $(\mathrm{Rp} / \mathrm{Kg})$ & $(12 a)=(5) x(7)$ \\
\hline & b. Pangsa Karyawan (\%) & $(12 b)=[(12 a) /(11 a)] \times 100 \%$ \\
\hline & a. Keuntungan/margin (Rp/Kg) & $(13 a)=(11 a)-(12 a)$ \\
\hline & b. Tingkat keuntungan (\%) & $(13 b)=[(13 a) /(11 a)] \times 100 \%$ \\
\hline \multicolumn{3}{|c|}{ III. Balas Jasa untuk Faktor Produksi } \\
\hline \multirow[t]{4}{*}{14} & Keuntungan/marjin (Rp/Kg) & $(14)=(10)-(8)$ \\
\hline & a.Pendapatan karyawan (\%) & $(14 a)=[(12 a) /(14)] \times 100 \%$ \\
\hline & b.Sumbangan pemasukan lainnya (\%) & $(14 b)=[(9) /(14)] \times 100 \%$ \\
\hline & c.Keuntungan/margin perusahaan (\%) & $(14 c)=[(13 a) /(14)] \times 100 \%$ \\
\hline
\end{tabular}

Sumber: Hayami, 1987.

\section{Sikap Konsumen Brownies Tepung Ubi Kayu Tinggi Protein}

Model analisis Fishbein digunakan dalam analisis sikap konsumen. Sumarwan (2011) analisis fishbein variabel sikap terdiri dari: (1) Faktor kepercayaan adalah respon konsumen pada daya terima brownies ubi kayu dan (2) Faktor evaluasi adalah respon konsumen pada produk brownies keseluruhan. Model analisis fishbein:

Keterangan :

$$
A o=\sum_{i=1}^{n} \text { bi. ei }
$$

Ao : Sikap konsumen pada produk brownies

bi : Tingkat kepercayaan konsumen bahwa produk brownies memiliki atribut i

ei : Tingkat kepentingan terhadap atribut i

$\mathrm{n}$ : Jumlah atribut (kelengkapan) produk brownies

Terdapat langkah untuk menghitung sikap konsumen yaitu: (1) tentukan atribut (kelengkapan) brownies tepung ubi kayu. Atribut tingkat kepercayaan (bi) harus sama dengan atribut evaluasi kepentingan. (2) Pengukuran tingkat kepercayaan(bi) dan evaluasi. Komponen (bi) untuk melihat kuat atau tidaknya konsumen yakin akan produk brownies memiliki 
kelengkapan atribut. Skala likert digunakan dalam penentuan ukuran kuantitatif berdasarkan penilaian konsumen. (3) Hitung rerata nilai tingkat kepentingan (ei) dan tingkat kepercayaan (bi) pada atribut brownies, selanjutnya pada setiap (bi) dikalikan dengan nilai evaluasi (ei) pada atribut brownies. Jumlah keseluruhan hasil perkalian dilakukan penjumlahan, sehingga diperoleh tanggapan responden (Ao) terhadap brownies tersebut yaitu menggunakan skala interval. Nilai kepentingan (ei) dan nilai kepercayaan (bi) konsumen kelengkapan produk dikelompokkan pada range skala yang tertera pada Tabel 2 berikut ini.

Tabel 2. Kriteria Tingkat Kepentingan dan Tingkat Kepercayaan

\begin{tabular}{llll}
\multicolumn{1}{c}{ Tingkat Kepentingan } & Nilai & Tingkat Kepercayaan & Nilai \\
Sangat Tidak Penting & $1.0 \leq \mathrm{ei} \leq 1.8$ & Sangat Buruk & $1.0 \leq \mathrm{ei} \leq 1.8$ \\
Tidak Penting & $1.8<\mathrm{ei} \leq 2.6$ & Buruk & $1.8<\mathrm{ei} \leq 2.6$ \\
Netral & $2.6<\mathrm{ei} \leq 3.4$ & Netral & $2.6<\mathrm{ei} \leq 3.4$ \\
Penting & $3.4<\mathrm{ei} \leq 4.2$ & Baik & $3.4<\mathrm{ei} \leq 4.2$ \\
Sangat Penting & $4.2<\mathrm{ei} \leq 5.0$ & Sangat Baik & $4.2<\mathrm{ei} \leq 5.0$
\end{tabular}

Sumber: Sumarwan, 2011.

Evaluasi sikap konsumen atribut (bi.ei) secara menyeluruh pada atribut brownies tepung ubi kayu tinggi protein diinterpretasikan kedalam 5 kelompok, yakni sangat negatif, negatif, netral (biasa), poaitif, dan sangat positif. Tabel 3 merupakan kriteria penilaian sikap konsumen brownies tepung ubi kayu tinggi protein (bi.ei) secara keseluruhan

Tabel 3. Kriteria Nilai Sikap Secara Keseluruhan Pada Atribut Brownies Tepung Ubi Kayu Tinggi protein

\begin{tabular}{lc}
\multicolumn{1}{c}{ Tingkat Kepentingan } & Nilai \\
\hline Sangat Negatif & $1.0 \leq \mathrm{ei} \leq 1.8$ \\
Negatif & $1.8<\mathrm{ei} \leq 2.6$ \\
Netral (biasa) & $2.6<\mathrm{ei} \leq 3.4$ \\
Positif & $3.4<\mathrm{ei} \leq 4.2$ \\
Sangat Positif & $4.2<\mathrm{ei} \leq 5.0$
\end{tabular}

Sumber: Sumarwan, 2011.

\section{Hasil dan Pembahasan \\ Nilai Tambah Produk Brownies}

Kegiatan pembuatan brownies merupakan kegiatan perubahan produk, sehingga menimbulkan nilai tambah. Analisis nilai tambah brownies tepung ubi kayu tinggi protein di laksanakan dalam satu kali produksi. Hasil analisis nilai tambah sebagai penentuan nilai tambah $/ \mathrm{kg}$, perbandingannya dalam $\%$, upah karyawan dalam $\mathrm{Rp} / \mathrm{kg}$, bagian karyawan dalam $\%$, margin dalam $\mathrm{Rp} / \mathrm{kg}$, dan tingkat margin dalam \%. Perhitungan nilai tambah brownies tepung ubi kayu tinggi protein pada Tabel 4. Brownies tepung ubi kayu tinggi protein yang diperoleh satu kali produksi seberat $6,50 \mathrm{~kg}$ dari tepung sebesar $10 \mathrm{~kg}$. Nilai faktor konversi merupakan hasil bagi dari nilai output dengan nilai input yaitu sebesar 0,98 , artinya setiap 1 kilogram tepung ubi kayu tinggi protein yang diolah akan menghasilkan $0,98 \mathrm{~kg}$ brownies. Faktor konversi sebesar $0,98 \mathrm{~kg}$ dikarenakan adanya tambahan bahan lain yaitu telur, gula pasir, margarin,vanili bubuk, baking powder, ovalet, coklat bubuk.

Karyawan dalam kegiatan pembuatan brownies sebanyak tiga orang. Karyawan bekerja selama tujuh jam kerja dalam satu hari. Pembagian total hari kerja dalam sekali produksi dengan jumlah bahan baku sekali produksi merupakan nilai koefisien karyawan yaitu 0,14. Nilai 0,14 mengartikan pengolahan $1 \mathrm{~kg}$ tepung ubi kayu tinggi protein menjadi brownies memerlukan karyawan 0,14 HOK/Kg dengan upah karyawan per hari Rp.50.000. Pendapatan karyawan langsung merupakan koefisien karyawan langsung dikalikan dengan upah karyawan langsung per kg adalah Rp.7038,29. Persentase upah karyawan pada nilai tambah sebesar 23,98\%. Upah terhadap modal dan keuntungan merupakan pengurangan nilai tambah dengan upah karyawan. Keuntungan usaha brownies tepung ubi kayu tinggi protein yaitu Rp. 22.317 dengan tingkat keuntungan $76,02 \%$ dari nilai produk.

Nilai input lain pembuatan brownies sebesar Rp 29.356/kg yang didapat dari biaya pemakaian bahan tambahan per kilogram sekali produksi. Nilai produk brownies Rp.58.800/kg merupakan perkalian antara faktor konversi dan harga produk. Nilai produk brownies tepung ubi kayu tinggi protein mengartikan setiap pengolahan $1 \mathrm{~kg}$ tepung ubi kayu tinggi protein menghasilkan Rp 58.800/kg. Perbandingan nilai tambah adalah pembagian antara nilai tambah 
dan nilai produk. Perbandingan nilai tambah yang didapatkan adalah $49.92 \%$ dengan kriteria nilai tambah yang tinggi dari nilai produk. Menurut Tambarta et al (2016) proporsi nilai tambah dan keuntungan dapat menggambarkan usaha produk olahan padat modal atau padat karya. Hasil marjin yang tinggi yang diperoleh dari usaha brownies tepung ubi kayu tinggi protein menggambarkan kategori usaha padat modal, hal ini berarti industri pengolahan brownies tepung ubi kayu tinggi protein menggantungkan proses produksi pada mesin dibandingkan sumber daya manusia. Penelitian sama dengan Henakin \& Taena (2018) didalam meningkatkan nilai tambah olahan ubi kayu menjadi keripik singkong memanfaatkan ala-alat mengunakan teknologi pengolahan lebih modern dengan menggunakan mesin.

Tabel 4. Nilai Tambah Brownies Tepung Ubi Kayu Tinggi protein

\section{No. Output, Input, dan Harga Nilai Olahan Brownies}

\begin{tabular}{llr}
\hline 1 & Output (kg/produksi) & 6,50 \\
2 & Pemasukan bahan baku (kg/produksi) & 6,66 \\
3 & Karyawan langsung (HOK/Produksi) & 0,94 \\
4 & Faktor peubah & 0,98 \\
5 & Koefisien karyawan & 0,14 \\
6 & Harga jual produk (Rp/unit) & 60.000 \\
7 & Upah rata-rata karywan per HOK $(\mathrm{Rp})$ & 50.000
\end{tabular}

\section{Penerimaan dan keuntungan}

$\begin{array}{lll}8 & \text { Harga pemasukan bahan baku }(\mathrm{Rp} / \mathrm{kg}) & 10.000\end{array}$

9 Sumbangan pemasukan $(\mathrm{Rp} / \mathrm{kg}) \quad 19.444$

10 Nilai pengeluaran $(\mathrm{Rp} / \mathrm{kg}) \quad 58.800$

11 a. Nilai Tambah $(\mathrm{Rp} / \mathrm{kg}) \quad 29.356$

$\begin{array}{lr}\text { b. Perbandingan nilai tambah (\%) } & 49,92\end{array}$

12 a.Pendapatan karyawan (Rp/kg) $\quad 7.038,29$

$\begin{array}{ll}\text { b. Imbalan karyawan } & 23,98\end{array}$

13 a.keuntungan $(\mathrm{Rp} / \mathrm{kg}) \quad 22.317$

$\begin{array}{ll}\text { b.Tingkat keuntungan (\%) } & 76,02\end{array}$

\section{Balas jasa untuk faktor produksi}

14 Marjin

a. Pendapatan karyawan

b Sumbangan pemasukan lain

c. Keuntungan bagi produsen (\%)
48.800

14,42

39,85

45,73

Sumber : Data Primer, 2020 (diolah)

Hasil analisis nilai tambah diperoleh marjin dari tepung ubi kayu menjadi brownies yang dibagi pada upah karyawan, sumbangan pemasukan lain, dan keuntungan bagi produsen. Marjin adalah selisih nilai produk dan harga tepung ubi kayu per kg. Setiap pembuatan $1 \mathrm{~kg}$ tepung ubi kayu tinggi protein menjadi brownies memperoleh marjin Rp.48.800 yang dibagi untuk karyawan langsung 14,42\%, sumbangan pemasukan lain 39,85\% dan keuntungan 45,73\%. Berdasarkan analisis nilai tambah usaha brownies tepung ubi kayu tinggi protein layak untuk dikembangkan. Sipayung et al., (2020) pengolahan produk pada dasarnya berfungsi 
meningkatkan nilai tambah ekonomi, memperpanjang daya tahan simpan, dan diversisifikasi produk yang dihasilkan, sehingga berpengaruh tehadap sosial ekonomi masyarakat.

\section{Analisis Sikap Konsumen Brownies Tepung Ubi Kayu Tinggi protein Tingkat Kepentingan (Evaluation)}

Sikap konsumen dipengaruhi oleh perilaku atau tindakan konsumen. Berdasarkan analisis fishbein diperoleh nilai kepentingan atribut brownies tepung ubi kayu tinggi protein yang tersaji pada Tabel 5

Tabel 5. Nilai Evaluasi (Ei) dan Kriteria Kepentingan Atribut Brownies Tepung Ubi Kayu Tinggi protein

\begin{tabular}{lccc}
\multicolumn{1}{c}{ Atribut } & Evaluasi Kepentingan (ei) & Kriteria Kepentingan & Urutan \\
\hline Rasa & 4.4 & Sangat penting & I \\
Harga & 4.2 & Penting & II \\
Warna & 4.16 & Penting & III \\
Kemasan & 4.04 & Penting & IV \\
Tekstur & 3.72 & Penting & V \\
Aroma & 3.68 & Penting & VI \\
\hline
\end{tabular}

Sumber : Data Primer, 2020 (diolah)

Hasil penilaian tingkat kepentingan atribut brownies tepung ubi kayu tinggi protein menunjukkan bahwa konsumen melakukan penilaian atribut brownies tepung ubi kayu tinggi prtotein sangat penting adalah rasa skor (4.4). Menurut Sumarwan (2011) atribut rasa merupakan salah satu faktor melakukan keputusan pembelian. Atribut yang penting bagi konsumen berjumlah lima atribut yaitu harga (4.2), warna (4.16), kemasan (4.04), tekstur (3.72) dan aroma (3.68). Skor rata-rata keseluruhan evaluasi atribut produk brownies tepung ubi kayu tinggi protein 4.03 pada kriteria penting dalam keputusan pembelian.

\section{Tingkat Kepercayaan}

Kepercayaan (bi) mengukur kepercayaan konsumen terhadap atribut produk brownies. Hasil evaluasi kepercayaan (bi) terhadap atribut brownies tepung ubi kayu tinggi protein disajikakn pada Tabel 6 .

Tabel 6. Kepercayaan (bi) dan Kriteria Penilaian Atribut Brownies Tepung Ubi Kayu Tinggi protein

\begin{tabular}{lccc}
\hline Atribut & Believe (Bi) & Kriteria Penilaian & Urutan \\
\hline Rasa & 4.12 & Baik & I \\
Harga & 4.04 & Baik & II \\
Kemasan & 3.52 & Baik & III \\
Tekstur & 3.32 & Biasa & IV \\
Warna & 3.24 & Biasa & V \\
Aroma & 3 & Biasa & VI \\
\hline
\end{tabular}

Sumber : Data Primer, 2020 (diolah)

Hasil penilaian Tabel 6 , tingkat pelaksanaan atribut brownies tepung ubi kayu tinggi protein diketahui bahwa konsumen memiliki keyakinan tentang rasa adalah atribut yang paling baik dengan nilai tertinggi sebesar 4.12 poin. Atribut yang dinilai baik selanjutnya adalah harga (4.04) dan kemasan (3.52). Sedangkan aroma memiliki nilai rerata terendah dan dinilai biasa saja kinerjanya adalah tekstur (3.32), warna (3.24) dan aroma (3).

\section{Sikap Konsumen Terhadap Atribut Brownies Tepung Ubi Kayu Tinggi Protein}

Kotler (2005) menyatakan sikap sebagai tindakan yang menunjukkan segala yang disukai atau tidak disukai oleh seseorang. Sikap ini baik berupa hal positif maupun negatif dari seseorang untuk melakukan suatu tindakan (Zukryandry et al., 2019). Hasil penelitian Tabel 7 bahwa sikap positif pada atribut rasa dengan skor 18,13. Atribut rasa yang paling disukai oleh konsumen brownies. Rasa enak adalah pertimbangan utama dalam melakukan pembelian brownies tepung ubi kayu tinggi protein. Terdapat tiga faktor dalam cita rasa yakni aroma, rasa, dan rangsangan mulut (Wahidah, 2010).

Harga menjadi pertimbangan konsumen dalam keputusan pembelian. Terutama bagi mereka yang memiliki pendapatan rendah. Atribut harga pada brownies tepung ubi kayu tinggi protein kategori positif sebesar 16.97. Harga brownies tepung ubi kayu tinggi protein Rp.60.000. 
Harga merupakan variabel penting didalam pemasaran, karena berhubungan dengan keuntungan dan penerimaan perusahaan.

Atribut yang memiliki kategori netral pada brownies tepung ubi kayu warna (13.48), kemasan (14.22), tekstur (12.35), dan aroma (11.04). Skor sikap konsumen brownies yaitu 86,19 poin. Seluruh konsumen memiliki tanggapan yang lebih positif terhadap brownies tepung ubi kayu tinggi protein pada atribut rasa dan harga.

Tabel 7. Sikap Konsumen Terhadap Atribut Brownies Tepung Ubi Kayu Tinggi protein

\begin{tabular}{lcccc}
\hline \multicolumn{1}{c}{ Atribut } & $\begin{array}{c}\text { Evaluasi } \\
\text { Kepentingan (ei) }\end{array}$ & $\begin{array}{c}\text { Skor Kepercayaan } \\
\text { (bi) }\end{array}$ & $\begin{array}{c}\text { Skor Sikap } \\
\text { Konsumen } \\
\text { (Ao) }\end{array}$ & Kategori \\
\hline Rasa & 4.4 & 4.12 & 18.13 & Positif \\
Harga & 4.2 & 4.04 & 16.97 & Positif \\
Warna & 4.16 & 3.24 & 13.48 & Netral \\
Kemasan & 4.04 & 3.52 & 14.22 & Netral \\
Tekstur & 3.72 & 3.32 & 12.35 & Netral \\
Aroma & 3.68 & 3.00 & 11.04 & Netral \\
\hline
\end{tabular}

Sumber : Data Primer, 2020 (diolah).

\section{SIMPULAN}

Nilai tambah yang diperoleh dari pembuatan brownies menggunakan tepung ubi kayu tinggi protein sebesar $\mathrm{Rp} 29.356 / \mathrm{kg}$ dengan rasio nilai tambah sebesar 49.92 kategori tinggi. Nilai sikap konsumen secara keseluruhan untuk brownies tepung ubi kayu tinggi protein sebesar 86.19 poin dengan kategori sikap positif. Atribut yang paling diminati konsumen dari produk brownies ubi kayu tinggi protein adalah rasa dan harga. Hal ini menunjukkan brownies tepung ubi kayu tinggi protein sudah sesuai dengan keinginan konsumen.

\section{Pustaka}

Adiyoga, W., \& Nurmalinda, N. (2013). Analisis Konjoin Preferensi Konsumen terhadap Atribut Produk Kentang, Bawang Merah, dan Cabai Merah. Jurnal Hortikultura, 22(3), 292. https://doi.org/10.21082/jhort.v22n3.2012.p292-302.

[BPS] Badan Pusat Statistik. (2018). STATISTIK INDONESIA 2018. Indonesia.

Hamidah, M., Yusra.A.H.A.,Sudrjat, J.S.(2015) ). Analisis Nilai Tambah Agroindustri Kripik Ubi Di Kota Pontianak. Jurnal Social Economic Of Agriculture, 4(2), 60-73.

Hayami, Yujiro, Kawagoe, T., Marooka, Y., dan Masdjidin, S. (1987). Agricultural Marketing and Processing in Upland Java A Perspective From A Sunda Village. Bogor: CGPRT Centre.

Henakin, F. K. O., \& Taena, W. (2018). Analisis Nilai Tambah Singkong Sebagai Bahan Baku Produk Keripik di Kelompok Usaha Bersama Sehati Desa Batnes Kecamatan Musi. Agrimor, 3(2), 23-26. https://doi.org/10.32938/ag.v3i2.246

Hidayat, B., Muslihudin, M., \& Akmal, S. (2018). Perubahan Karakteristik Fisikokimia Tepung Onggok Selama Proses Fermentasi Semi Padat Menggunakan Saccharomyces cerevisiae Changes in Physicochemical Characteristics of Cassava Bagasse Flour During Semi-Solid Fermentation Process Using Saccharomyces cerev. 18(3), 146-152.

Husniah, F. A., Hapsari, T. D., \& Agustina, T. (2019). Analisis Nilai Tambah Agroindustri Kerupuk Tempe di Kecamatan Puger Kabupaten Jember. Jurnal Ekonomi Pertanian Dan Agribisnis, 3(1), 195-203. https://doi.org/10.21776/ub.jepa.2019.003.01.19.

Kotler, P. (2005). Manajemen Pemasaran (I dan II). Jakarta: PT. Indeks.

Mumpuningsih, G. (2008). Analisis Nilai Tambah dan PenerimaanAgroindustri Tiwul Instant di Malang Selatan. Jurnal Penelitian Pertanian Tropika, 16, 88-98.

Ruauw, E. (2015). Analisis Keuntungan Dan Nilai Tambah Agriindustri Manisan Pala Ud Putri Di $\begin{array}{llll}\text { Kota } & \text { Bitung. } & \text { Agri-Sosioekonomi, } & 8(1),\end{array}$ https://doi.org/10.35791/agrsosek.8.1.2012.7359.

Sari, I. N., Hidayat, B., Zukryandry, Z., \& Fitri, A. (2020). Substitusi Tepung Ubi Kayu Tinggi Protein Terhadap Sifat Kimia Dan Sensoris Brownies Kukus. Majalah TEGI, 12(1), 1. https://doi.org/10.46559/tegi.v12i1.5969.

Sipayung, M. L., Ginting, R. A., Lldikti, D., Dpk, W., Universitas, F., Agung, D., \& Utara, S. (2020). Analisis Nilai Tambah Pengolahan Ubi Kayu ( Manihot Utilissima ) ( Studi Kasus Desa Deli Tua Kecamatan Namorambe Kabupaten Deli Serdang ). Jurnal Agrilink, 9(2), 6270 . 
Sumarwan, U. (2011). Perilaku Konsumen: Teori dan Penerapannya dalam Pemasaran (2nd ed.; R. Sikumbang, Ed.). Bogor: Ghalia Indonesia.

Susanto, D. G. (2013). Profitabilitas Usaha Pengolahan Serta Nilai Tambah Produk Ubi Jalar Pada Kelompok Tani Hurip Di Desa Cikarawang, Bogor.

Tambarta, E., Tinaprilla, N., \& Adhi, A. K. (2016). Analysis Added-ValueAnd Development Strategic of Gayo Coffe Products in Bener Meriah Aceh. 5(11), 515-519. https: / / doi.org/10.21275/ART20162754.

Wahidah, N. (2010). Komponen - Komponen yang Memengaruhi Cita Rasa Bahan Pangan.

Zukryandry., Hidayat,B., Berliana, D. (2019). Analisis preferensi konsumen dan proksimat cookies bebas gluten berbahan baku tepung ubi kayu ( manihot utilissima ) tinggi protein. Jurnal Administrasi Bisnis (JAB)ournal of Food System and Agribusiness, 3(2), 63-71 